\title{
INVERSÃO QUADRÁTICA DE DADOS DE AVO USANDO ALGORITMO DE MARQUARDT
}

\author{
Ana Cristina Marques Mendes \\ Orientador: Dr. João dos Santos Protázio (UFPA) \\ 52 p. - Dissertação (Mestrado) - Defesa 17.12.2004
}

\begin{abstract}
RESUMO. Neste trabalho são apresentadas expressões exatas e aproximações quadráticas das conhecidas equações de Knott-Zöeppritz, que calculam as amplitudes dos coeficientes Rpp e Rsp em termos dos contrastes médios relativos, bem como é procedida a inversão dos parâmetros de dados de AVO a partir destas aproximações quadráticas. Nesta inversão é utilizado o algoritmo de Levenberg-Marquardt, e são considerados apenas os eventos refletidos Rpp e convertidos Rsp, não associados. Nos estudos dos parâmetros físicos dos meios contrastes de impedância $(\overline{\delta z})$, módulo de cisalhamento $(\overline{\delta u})$ e velocidade da onda $\mathrm{p}(\overline{\delta \alpha})$, verificou-se quais desses parâmetros podem ser invertidos. Os resultados obtidos mostram que 0 contraste de impedância $(\overline{\delta z})$ é muito bem resolvido estando ele relacionado com o contraste de velocidade da onda p $(\overline{\delta \alpha})$ ou com 0 contraste de cisalhamento $(\overline{\delta u})$, no caso de eventos refletidos considerando modelos de alto, moderado e baixo contrastes. Por outro lado ao se fixar o contraste de impedância e relacionar os outros dois parâmetros em consideração, os resultados mostram que esses são mal resolvidos, ou seja, a região de ambigüidade torna-se muito grande e os parâmetros tornam-se ambíguos e instáveis. No caso do evento convertido e na combinação do evento refletido com o convertido, para os modelos de baixo e moderado contrastes, $(\overline{\delta z})$ é muito bem resolvido, caso que não acontece para modelo de alto contraste. Diante desses resultados verifica-se que no procedimento de inversão quadrática de dados de AV0, fixado $(\overline{\delta u})$, a recuperação dos dois parâmetros variados é muito boa, no caso do evento refletido, e razoavelmente boa no caso do evento convertido, por esse motivo optou-se pela fixação do módulo de cisalhamento.
\end{abstract}

ABSTRACT. In this work, the exact and quadratic approach expression of Knott-Zöeprtiz are presented, as well as its coefficients, amplitudes, Rpp and Rsp, respectively, all of them as a function of the relative contrast, as well as the inversion of quadratic parameters of AVO data. In this inversion of the quadratic parameters, we have used the non-linear Levenberg-Marquardt algorithm, considering only converted and reflected events, either in the non-combined form. In the study of the physical parameters impedance contrast, shear modulus and $P$ wave velocity, we have verified which of those parameters can be effectively inverted. The results have shown that the impedance contrast $(\overline{\delta z})$ is very well solved when it is related with the $\mathrm{P}$ wave velocity contrast $(\overline{\delta \alpha})$ or with the shear contrast $(\overline{\delta u})$, considering reflected events in the case of high, moderate and low model contrasts. On the other hand, when the impedance constrast is fixed and the two other parameters in consideration are related, the results show that these parameters are bad solved, e.g., the ambiguity region becomes large and the parameters become ambiguous and unstable. In the case of a converted event and in the combination of converted and reflected events, considering low and moderate contrast models $(\overline{\delta z})$ is well solved, which is not the case when we consider a high contrast model. 